\title{
PENGOLAHAN AIR LIMBAH DOMESTIK DENGAN PROSES LUMPUR AKTIF YANG DIISI DENGAN MEDIA BIOBALL
}

\author{
Oleh : \\ Nusa Idaman Said ${ }^{*}$ dan Kristianti Utomo **) \\ *) Pusat Teknologi Lingkungan, BPPT. \\ ${ }^{\star *}$ ) Mahasiswa Pasca Sarjana Ilmu Lingkungan, Universitas Indonesia.
}

\begin{abstract}
Recently, the treatment process of waste water contains organic pollutant which used in Indonesia especially in Jakarta is activated sludge process. The problem is its treated water quality which frequently does not yet fulfilled to effluent standard of wastewater. Some affecting factors are hydraulic retention time (HRT) too short, the fluctuation of wastewater flow rate, unfavorable function of aeration process and also which do not less important is operational mistake caused by insufficient knowledge of operator. To overcome the mentioned problems it is needed technological innovation to increase efficiency of wastewater treatment process especially activated sludge process.

This paper describes the study of domestic waste water treatment using activated sludge process which is filled with bioball plastic media for attaching microorganism to increase efficiency and keep stability of process.

Result of the study shows that within 6 hours hydraulic retention time (HRT), the removal efficiency of COD, BOD, Ammonia and Total Suspended Solids (TSS) were 78.42\%, $79.41 \%, 61.41 \%$, and $82.06 \%$ respectively. The most effective of sludge circulation ratio is $R=0,5 Q$. In sludge circulation ratio $R=0,5 Q$, the removal efficiency of $C O D, B O D$, organic loading coming into bioreactor, the lower removal efficiency. In organic loading (BOD loading) $0.3-1.0 \mathrm{kgBOD} / \mathrm{m}^{3}$. day, the removal efficiency of $B O D$ was $80-85 \%$.
\end{abstract}

Kata kunci : Air limbah domestik, lumpur aktif, bioball, aerob.

\section{PENDAHULUAN}

\subsection{Permasalahan}

Masalah pencemaran lingkungan khususnya masalah pencemaran air di kota besar di Indonesia, telah menunjukkan gejala yang cukup serius. Penyebab dari pencemaran tadi tidak hanya berasal dari buangan industri dari pabrikpabrik yang membuang begitu saja air limbahnya tanpa pengolahan lebih dahulu ke sungai atau ke laut, tetapi juga yang tidak kalah memegang andil baik secara sengaja sendiri, yakni akibat air buangan rumah tangga yang jumlahnya makin hari makin besar sesuai dengan perkembangan penduduk maupun perkembangan kota. Ditambah lagi rendahnya kesadaran sebagian masyarakat yang langsung membuang kotoran/tinja maupun sampah ke dalam sungai, menyebabkan proses pencemaran sungaisungai yang ada bertambah cepat.

Sebagai contoh, dengan semakin besarnya laju perkembangan penduduk dan industrialisasi di Jakarta, telah mengakibatkan terjadinya penurunan kualitas lingkungan. Padatnya pemukiman dan kondisi sanitasi lingkungan yang buruk serta buangan industri yang langsung dibuang ke badan air tanpa proses pengolahan telah menyebabkan pencemaran sungai-sungai yang ada di Jakarta, dan air tanah dangkal di sebagian besar daerah di wilayah DKI Jakarta, bahkan kualitas air di perairan teluk Jakartapun sudah menjadi semakin buruk.

Air limbah kota-kota besar di Indonesia khususnya Jakarta secara garis besar dapat dibagi menjadi tiga yaitu air limbah industri dan air limbah domestik yakni yang berasal dari buangan rumah tangga dan yang ke tiga yakni air limbah dari perkantoran dan pertokoan (daerah komersial). Saat ini selain pencemaran akibat limbah industri, pencemaran akibat limbah domestikpun telah menunjukkan tingkat yang cukup serius. Di Jakarta misalnya, sebagai akibat masih minimnya fasilitas pengolahan air buangan kota (sewerage system) mengakibatkan tercemarnya badan - badan sungai oleh air limbah domestik, bahkan badan sungai yang diperuntukkan sebagai bahan baku air minumpun telah tercemar pula. Dari hasil penelitian yang dilakukan oleh Dinas Pekerjaan Umum (PU) DKI Jakarta bersama-sama dengan Tim JICA (JICA,1990), jumlah unit air limbah dari buangan rumah tangga per orang per hari adalah 118 liter dengan konsentrasi BOD ratarata $236 \mathrm{mg} / \mathrm{lt}$ dan pada tahun 2010 diperkirakan akan meningkat menjadi 147 liter dengan konsetrasi BOD rata-rata $224 \mathrm{mg} / \mathrm{lt}$. 
Jumlah air limbah secara keseluruhan di DKI Jakarta diperkirakan sebesar 1.316.113 $\mathrm{M}^{3} /$ hari yakni untuk air limbah domestik 1.038.205 $\mathrm{M}^{3} /$ hari, air limbah yang berasal dari perkantoran dan daerah komersial 448.933 $\mathrm{M}^{3} /$ hari dan air limbah industri $105.437 \mathrm{M}^{3} /$ hari. Dilihat dari segi jumlah, air limbah domestik (rumah tangga) memberikan kontribusi terhadap pencemaran air sekitar $75 \%$, air limbah yang berasal dari perkantoran dan daerah komersial $15 \%$, dan air limbah industri hanya sekitar $10 \%$. Sedangkan dilihat dari beban polutan organiknya, air limbah rumah tangga sekitar 70 $\%$, air limbah perkantoran $14 \%$, dan air limbah industri memberikan kontribusi $16 \%$ (JICA, 1990). Dengan demikan air limbah rumah tangga dan air limbah perkantoran adalah penyumbang yang terbesar terhadap pencemaran air di wilayah DKI Jakarta.

Masalah pencemaran oleh air limbah rumah tangga di wilayah DKI Jakarta lebih diperburuk lagi akibat berkembangnya lokasi pemukiman di daerah penyangga yang ada di sekitar Jakarta, yang mana tanpa dilengkapi dengan fasilitas pengolahan air limbah, sehingga seluruh air limbah dibuang ke saluran umum dan akhirnya mengalir ke badan-badan sungai yang ada di wilayah DKI Jakarta. Di lain pihak laju pembanguan fasilitas pengolahan air limbah perkotaan masih sangat rendah yakni sampai saat ini prosentase pelayanan hanya sekitar 2,5$3 \%$.(PD. PAL JAYA, 199-)

Untuk mengatasi hal tersebut di atas Pemerintah Provinsi DKI Jakarta telah mengeluarkan Peraturan Gubernur Propinsi Daerah Khusus Ibukota Jakarta Nomor 122 Tahun 2005 Tentang Pengelolaan Air Limbah Domestik Di Propinsi Daerah Khusus Ibukota Jakarta.

Menurut Peraturan Gubernur Nomor 122 tahun 2005 Bab V pasal 7 tersebut telah mewajibkan untuk mengolah air limbah domestik sebelum dibuang kesaluran umum. Bangunan rumah tinggal atau bangunan non rumah tinggal wajib mengelola air limbah domestik (black water maupun grey water) sebelum dibuang ke saluran umum/drainase. Bangunan rumah tinggal dan atau bangunan usaha/ jasa/ industri yang telah dibangun dan belum memiliki instalasi pengelolaan air limbah domestik yang memenuhi syarat baku mutu air limbah, wajib memperbaiki dan atau membangun instalasi pengolahan air limbah domestik.

Untuk mengolah air limbah domestik proses yang umum digunaan adalah proses pengolahan secara biologis, yakni menggunakan aktifitas mikro-organisme untuk menguraikan senyawa polutan organik yang ada di dalam air limbah. Pengolahan air limbah secara bilogis secara garis besar dapat dibagi menjadi tiga yakni proses biologis dengan biakan tersuspensi (suspended culture), proses biologis dengan biakan melekat (attached culture) dan proses pengolahan dengan sistem lagoon atau kolam.

Proses biologis dengan biakan tersuspensi adalah sistem pengolahan dengan menggunakan aktifitas mikro-organisme untuk menguraikan senyawa polutan yang ada dalam air dan mikro-organime yang digunakan dibiakkan secara tersuspesi di dalam suatu reaktor. Beberapa contoh proses pengolahan dengan sistem ini antara lain : proses lumpur aktif standar atau konvesional (standard activated sludge), step aeration, contact stabilization, extended aeration, oxidation ditch (kolam oksidasi sistem parit) dan lainya (JSWA, 1979).

Proses biologis dengan biakan melekat yakni proses pengolahan limbah dimana mikroorganisme yang digunakan dibiakkan pada suatu media sehingga mikroorganisme tersebut melekat pada permukaan media. Proses ini disebut juga dengan proses film mikrobiologis atau proses biofilm. Teknologi pengolahan air limbah dengan cara ini antara lain : trickling filter, biofilter tercelup, reaktor kontak biologis putar (rotating biological contactor , RBC), contact aeration/oxidation (aerasi kontak) dan lainnnya (JSWA, 1979).

Proses pengolahan air limbah secara biologis dengan lagoon atau kolam adalah dengan menampung air limbah pada suatu kolam yang luas dengan waktu tinggal yang cukup lama sehingga dengan aktifitas mikroorganisme yang tumbuh secara alami, senyawa polutan yang ada dalam air akan terurai. Untuk mempercepat proses penguraian senyawa polutan atau memperpendek waktu tinggal dapat juga dilakukan proses aerasi. Salah satu contoh proses pengolahan air limbah dengan cara ini adalah kolam aerasi atau kolam stabilisasi (stabilization pond). Proses dengan sistem lagoon tersebut kadang-kadang dikategorikan sebagai proses biologis dengan biakan tersuspensi.

Proses pengolahan air limbah yang mengandung polutan organik yang banyak digunakan di Indonesia khususnya di Jakarta saat ini adalah proses lumpur aktif (activated sludge). Permasalahan yang banyak dihadapi adalah air hasil olahannya sering kali belum memenuhi baku mutu air limbah yang boleh dibuang sesuai dengan Pergub DKI jarta nomor 122 tahun 2005. Parameter yang sering melampaui baku mutu adalah parameter amoniak $\left(\mathrm{NH}_{4}^{+}\right)$. Beberapa faktor penyebab yang sering ditemui antara lain adalah waktu tinggal hidrolik terlalu singkat, fluktuasi debit limbah yang sangat besar, fungsi aerasi yang kurang baik, serta yang tidak kalah penting adalah 
kesalahan operasional akibat pengetahuan operator tentang proses yang tidak memadai.

Untuk mengatasi hal tersebut di atas, perlu inovasi teknologi untuk meningkatkan efisiensi pengolahan air limbah khususnya proses lumpur aktif (activated sludge). Salah satu contoh untuk meningkatkan proses lumpur aktif adalah dengan cara menambahkan karbon aktif ke dalam bak aerasi. Dengan menambahkan karbon aktif ke dalam bak areasi maka mikroorganisme akan tumbuh dan berkembang di permukaan karbon aktif sehingga jumlah mikroorganisme yang menguraikan polutan organik di dalam bak areasi menjadi lebih banyak sehingga efisiensi pengolahan menjadi lebih stabil. (Sublette, 1982).

Weber, Hopkin dan Bloom (1970) mempublikasikan hasil penelitiannya yang menyimpulkan bahwa mikroorganisme yang tumbuh di permukaan karbon aktif dapat mempertahankan efisiensi pada pengolahan air limbah lanjut (advanced treatment) dengan karbon granular (burtiran). Sedangkan Miller dan Rice (1960) telah memastikan adanya aktifitas biologis pada filter karbon aktif di dalam sistem pengolahan air dengan ozon dan karbon aktif butiran. Dengan demikian, sebenarnya phenomena penambahan karbon aktif ke dalam proses biologis ini bukanlah hal yang baru.

Di dalam proses pengolahan secara biologis dengan penambahan karbon aktif, bakteri nitrifikasi yang tumbuh dan melekat di permukaan karbon aktif dapat merangsang atau mempercepat proses nitrifikasi senyawa ammoniun-nitrogen.

Kurozawa dkk. (1978) telah melakukan pengukuran kecepatan proses nitrifikasi ammonia di dalam sistem saringan pasir cepat, yakni satu diisi dengan media pasir dan satu lagi diisi dengan karbon aktif butiran. Dari hasil pengukuran tersebut ternyata bakteri nitrifikasi yang tumbuh di permukaan karbon aktif mempunyai kecepatan nitrifikasi beberapa kali lebih cepat dari pada nitrifikasi di dalan saringan pasir cepat dengan media pasir, serta memerlukan waktu yang lebih pendek untuk mencapai efisiensi pengolahan yang konstan. Selain itu, pengaruh temperatur terhadap proses nitrifikasi oleh bakteri atau mikroorganisme yang tumbuh di permukaan karbon aktif lebih kecil dibandingkan dengan pengaruh nitrifikasi oleh bakteri yang tumbuh di permukaan saringan pasir. Akan tetapi mekanisme prosesnya belum diketahui secara jelas.

Paper ini membahas tentang pengolahan air limbah domestik dengan proses lumpur aktif yangi diisi dengan media bioball sebagai tempat melekat mikroorganisme untuk meningkatkan efisiensi serta menjaga stabilitas proses. Dengan penambahan media bioball ke dalam bak aerasi maka proses pengolahan yang terjadi di dalam rekator biologis (bioreaktor) adalah proses biakan tersuspensi dan biakan melekat terjadi secara bersama-sama. Dengan cara demikan diharapkan selain meningkatkan jumlah mikroorganisme yang menguraikan polutan juga suplai oksigen akan lebih merata sehingga kemampuan penyerapan oksigen menjadi lebih besar.

\subsection{TINJAUAN PUSTAKA}

\subsubsection{Pengolahan Air Limbah Domestik Dengan Proses Lumpur Aktif}

\subsubsection{Proses pengolahan}

Pengolahan air limbah domestik dengan proses lumpur aktif konvensional (standar) secara umum terdiri dari bak pengendap awal, bak aerasi dan bak pengendap akhir, serta bak khlorinasi untuk membunuh bakteri patogen. Secara umum proses pengolahannya adalah sebgai berikut. Air limbah yang berasal dari ditampung ke dalam bak penampung air limbah. Bak penampung ini berfungsi sebagai bak pengatur debit air limbah serta dilengkapi dengan saringan kasar untuk memisahkan kotoran yang besar. Kemudian, air limbah dalam bak penampung di pompa ke bak pengendap awal.

Bak pengendap awal berfungsi untuk menurunkan padatan tersuspensi (Suspended Solids) sekitar 30 - $40 \%$, dan BOD sekitar $25 \%$. Air limpasan dari bak pengendap awal dialirkan ke bak aerasi secara gravitasi. Di dalam bak aerasi ini air limbah dihembus dengan udara sehingga mikro organisme yang ada akan menguraikan zat organik yang ada dalam air limbah. Energi yang didapatkan dari hasil penguraian zat organik tersebut digunakan oleh mikrorganisme untuk proses pertumbuhannya. Dengan demikian didalam bak aerasi tersebut akan tumbuh dan berkembang biomasa dalam jumlah yang besar. Biomasa atau mikroorganisme inilah yang akan menguraikan senyawa polutan yang ada di dalam air limbah.

Dari bak aerasi, air dialirkan ke bak pengendap akhir. Di dalam bak ini lumpur aktif yang mengandung massa mikro-organisme diendapkan dan dipompa kembali ke bagian inlet bak aerasi dengan pompa sirkulasi lumpur. Air limpasan (over flow) dari bak pengendap akhir dialirkan ke bak khlorinasi. Di dalam bak kontaktor khlor ini air limbah dikontakkan dengan senyawa khlor untuk membunuh microorganisme patogen. Air olahan, yakni air yang keluar setelah proses khlorinasi dapat langsung dibuang ke sungai atau saluran umum. Dengan proses ini air limbah dengan konsentrasi BOD $250-300 \mathrm{mg} / \mathrm{lt}$ dapat di turunkan kadar BOD nya 
menjadi $20-30 \mathrm{mg} / \mathrm{lt}$. Skema proses pengolahan air limbah dengan sistem lumpur aktif standar atau konvesional dapat dilihat pada Gambar 1.

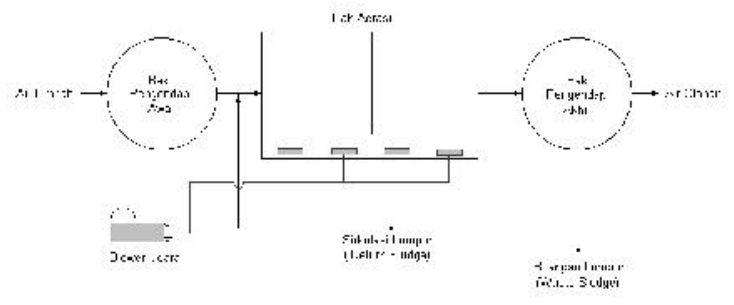

Gambar 1: Diagram Proses Pengolahan Air Limbah Dengan Proses Lumpur Aktif Standar (Konvensional).

Surplus lumpur dari bak pengendap awal maupun akhir ditampung ke dalam bak pengering lumpur, sedangkan air resapannya ditampung kembali di bak penampung air limbah. Keunggulan proses lumpur aktif ini adalah dapat mengolah air limbah dengan beban BOD yang besar, sehingga tidak memerlukan tempat yang besar. Proses ini cocok digunakan untuk mengolah air limbah dalam jumlah yang besar. Sedangkan beberapa kelemahannya antara lain yakni kemungkinan dapat terjadi bulking pada lumpur aktifnya, terjadi buih, serta jumlah lumpur yang dihasilkan cukup besar. Selain itu memerlukan ketrampilan operator yang cukup.

\subsubsection{Variabel Operasional Di Dalam Proses Lumpur Aktif}

Variabel perencanan (design variabel) yang umum digunakan dalam proses pengolahan air limbah dengan sistem lumpur aktif adalah sebagai berikut:

\section{A. Beban BOD (BOD Loading rate atau Volumetric Loading rate).}

Beban BOD adalah jumlah massa BOD di dalam air limbah yang masuk (influent) dibagi dengan volume reaktor. Beban BOD dapat dihitung dengan rumus sebagai berikut :

$$
\text { Beban BOD }=\frac{\mathrm{Q} \times \mathrm{S}_{0}}{\mathrm{~V}} \mathrm{~kg} / \mathrm{m}^{3} \text {.hari }
$$

Dimana :

$\mathrm{Q}=$ debit air limbah yang masuk ( $\left.\mathrm{m}^{3} / \mathrm{hari}\right)$

$\mathrm{S}_{0}=$ Konsentrasi BOD di dalam air limbah yang masuk $\left(\mathrm{kg} / \mathrm{m}^{3}\right)$

$\mathrm{V}=$ Volume reaktor $\left(\mathrm{m}^{3}\right)$

Untuk untuk proses lumpur aktif standar beban BOD umumnya kerkisar antara $0,3-0,8$ $\mathrm{kg} / \mathrm{m}^{3}$.hari, sedangkan untuk proses lumpur aktif Extended Areation beban BOD yang umum digunakan berkisar antara $0,15-0,25$ $\mathrm{kg} / \mathrm{m}^{3}$.hari. (JSWA, 1979).

\section{B. Mixed-liqour suspended solids (MLSS).}

Isi di dalam bak aerasi pada proses pengolahan air limbah dengan sistem lumpur aktif disebut sebagai mixed liqour yang merupakan campuran antara air limbah dengan biomassa mikroorganisme serta padatan tersuspensi lainnya. MLSS adalah jumlah total dari padatan tersuspensi yang berupa material organik dan mineral, termasuk di dalamnya adalah mikroorganisme. MLSS ditentukan dengan cara menyaring lumpur campuran dengan kertas saring (filter), kemudian filter dikeringkan pada temperatur $105^{\circ} \mathrm{C}$, dan berat padatan dalam contoh ditimbang.

\section{Mixed-liqour volatile suspended solids (MLVSS).}

Porsi material organik pada MLSS diwakili oleh MLVSS, yang berisi material organik bukan mikroba, mikroba hidup dan mati, dan hancuran sel (Nelson dan Lawrence, 1980). MLVSS diukur dengan memanaskan terus sampel filter yang telah kering pada $600-650^{\circ} \mathrm{C}$, dan nilainya mendekati $65-75 \%$ dari MLSS.

\section{Food - to - microorganism ratio atau Food - to - mass ratio disingkat F/M Ratio.}

Parameter ini menujukkan jumlah zat organik (BOD) yang dihilangkan dibagi dengan jumlah massa mikroorganisme di dalam bak aerasi atau reaktor. Besarnya nilai $F / M$ ratio umumnya ditunjukkan dalam kilogram BOD per kilogram MLLSS per hari. F/M dapat dihitung dengan menggunakan rumus sebagai berikut :

$$
F / M=\frac{Q\left(S_{0}-S\right)}{M L S S \times V}
$$

dimana :

$\mathrm{Q}=$ Laju alir limbah $\mathrm{m}^{3}$ per hari.

$\mathrm{S}_{0}=$ Konsentrasi BOD di dalam air limbah yang masuk ke bak areasi (reaktor) $\left(\mathrm{kg} / \mathrm{m}^{3}\right)$.

$\mathrm{S}=$ Konsentrasi BOD di dalam efluent $\left(\mathrm{kg} / \mathrm{m}^{3}\right)$.

MLSS = Mixed liquor suspended solids $\left(\mathrm{kg} / \mathrm{m}^{3}\right)$.

$\mathrm{V}=$ Volume reaktor atau bak aerasi $\left(\mathrm{m}^{3}\right)$.

Rasio F/M dapat dikontrol dengan cara mengatur laju sirkulasi lumpur aktif dari bak pengendapan akhir yang disirkulasi ke bak aerasi. Lebih tinggi laju sirkulasi lumpur aktif lebih tinggi pula rasio F/M-nya. Untuk pengolahan air limbah dengan sistem lumpur aktif konvensional atau standar, rasio $\mathrm{F} / \mathrm{M}$ adalah $0,2-0,5 \mathrm{~kg} \mathrm{BOD}$ per $\mathrm{kg}$ MLSS per hari, tetapi dapat lebih tinggi hingga 1,5 jika digunakan oksigen murni (Hammer, 1986). Rasio F/M yang rendah menujukkan bahwa 
mikroorganisme dalam tangki aerasi dalam kondisi lapar, semakin rendah rasio F/M pengolah limbah semakin efisien.

\section{E. Hidraulic retention time (HRT).}

Waktu tinggal hidrolik (HRT) adalah waktu rata-rata yang dibutuhkan oleh air limbah masuk dalam bak atau tangki aerasi. Untuk proses lumpur aktif, nilainya berbanding terbalik dengan laju pengenceran (dilution rate, $D$ ).

$$
\mathrm{HRT}=1 / \mathrm{D}=\mathrm{V} / \mathrm{Q}
$$

dimana :

$\mathrm{V}=$ Volume reaktor atau bak aerasi $\left(\mathrm{m}^{3}\right)$.

$Q=$ Debit air limbah yang masuk ke dalam

Tangki aerasi ( $\left.\mathrm{m}^{3} / \mathrm{jam}\right)$

$\mathrm{D}=$ Laju pengenceran $\left(\mathrm{jam}^{-1}\right)$.

\section{F. Ratio Sirkulasi Lumpur (Hidraulic Recycle Ratio, HRT).}

Ratio sirkulasi lumpur adalah perbandingan antara jumlah lumpur yang disirkulasikan ke bak aerasi dengan jumlah air limbah yang masuk ke dalam bak aerasi.

\section{G. Umur Lumpur (sludge age)}

Umur lumpur sering disebut waktu tinggal rata-rata cel (mean cell residence time). Parameter ini menujukkan waktu tinggal rata-rata mikroorganisme dalam sistem lumpur aktif. Jika HRT memerlukan waktu dalam jam, maka waktu tinggal sel mikroba dalam bak aerasi dapat dalam hitungan hari. Parameter ini berbanding terbalik dengan laju pertumbuhan mikroba. Umur lumpur dapat dihitung dengan rumus sebagai berikut (Hammer, 1986) :

Umur Lumpur (Hari) =

$$
=\frac{M L S S \times V}{S S_{e} \times Q_{e}+S S_{w} \times Q_{w}}
$$

dimana :

MLSS = Mixed liquor suspended solids ( $\mathrm{mg} / \mathrm{l})$.

$\mathrm{V}=$ Volume bak aerasi (L)

$\mathrm{SS}_{\mathrm{e}}=$ Padatan tersuspensi dalam effluent (mg/l).

$\mathrm{SS}_{\mathrm{w}}=$ Padatan tersuspensi dalam lumpur limbah (mg/l)

$\mathrm{Q}_{\mathrm{e}} \quad=$ Laju effluent limbah ( $\mathrm{m}^{3} /$ hari)

$\mathrm{Q}_{w}=$ Laju influent limbah ( $\mathrm{m}^{3} /$ hari).

Umur lumpur dapat bervariasi antara 5-15 hari untuk sistem lumpur aktif konvensional. Pada musim dingin dapat menjadi lebih lama dibandingkan pada musim panas. Parameter penting yang mengendalikan operasi lumpur aktif adalah beban organik atau beban BOD, suplai oksigen, dan pengendalian dan operasi bak pengendapan akhir. Bak pengendapan akhir ini mempunyai dua fungsi yakni untuk penjernihan (clarification) dan pemekatan lumpur (thickening).

Campuran air limbah dan lumpur (mixed liqour) dipindahkan dari tangki aerasi ke bak pengendapan akhir. Di dalam bak pengendapan akhir lumpur yang mengandung mikroorganisme yang masih aktif dipisahkan dari air limbah yang telah diolah. Sebagian dari lumpur yang masih aktif ini dikembalikan ke bak aerasi dan sebagian lagi dibuang dan dipindahkan ke pengolahan lumpur. Sel-sel mikroba terjadi dalam bentuk agregat atau flok, densitasnya cukup untuk mengendap dalam tangki penjernih.

Pengendapan lumpur tergantung ratio $F / M$ dan umur lumpur. Pengendapan yang baik dapat terjadi jika lumpur mikroorganisme berada dalam fase endogeneous, yang terjadi jika karbon dan sumber energi terbatas dan jika pertumbuhan bakteri rendah. Pengendapan lumpur yang baik dapat terjadi pada rasio $F / M$ yang rendah (contoh : tingginya konsentrasi MLSS). Sebaliknya, Rasio F/M yang tinggi mengakibatkan pengendapan lumpur yang buruk.

Untuk air limbah domestik, rasio F/M yang optimum adalah 0,2 - 0,5 (Gaudy, 1988; Hammer, 1986). Rata-rata waktu tinggal sel yang diperlukan untuk pengendapan yang efektif adalah 3 - 4 hari (Metcalf dan Eddy, 1991). Pengendapan yang tidak baik dapat terjadi akibat gangguan yang tiba-tiba pada parameter fisik (suhu dan pH), kekurangan makanan (contoh N, suhu, mikro-nutrien), dan kehadiran zat racun (seperti logam berat) yang dapat menyebabkan hancurnya sebagian flok yang sudah terbentuk. Untuk operasi rutin, operator harus mengukur laju pengendapan lumpur dengan menentukan indeks volume lumpur.

Cara konvensional untuk mengamati kemampuan pengendapan lumpur adalah dengan menentukan Indeks Volume Sludge (Sludge Volume Index = SVI). Caranya adalah sebagai berikut : campuran lumpur dan air limbah (mixed liquor) dari bak aerasi dimasukkan dalam silinder kerucut volume 1 liter dan dibiarkan selama 30 menit. Volume sludge dicatat. SVI adalah menunjukkan besarnya volume yang ditempati 1 gram lumpur (sludge). SVI dapat dihitung dengan menggunakan rumus sebagai berikut :

$$
\operatorname{SVI}(\mathrm{ml} / \mathrm{g})=\frac{S V \times 1000}{M L S S} \mathrm{~mm} / \mathrm{gr} .
$$

dimana :

SV = Volume endapan lumpur di dalam silinder kerucut setelah 30 menit pengendapan $(\mathrm{ml})$. 
MLSS = adalah mixed liqour suspended solid (mg/l).

Di dalam unit pengolahan air limbah dengan sistem lumpur aktif konvensional dengan MLSS < $3500 \mathrm{mg} / \mathrm{l}$ ) nilai SVI yang normal adalah berkisar antara 50 - $150 \mathrm{ml} / \mathrm{gr}$.

Mengingat parameter operasional di dalam proses lumpur aktif yang harus dikontrol sangat banyak maka proses pengolahan air limbah dengan proses lumpur aktif cukup rumit dan memerlukan keahlian operator yang cukup.

\subsubsection{Pengolahan air limbah dengan Proses Biofilm Atau Biofilter Tercelup (Submerged Biofilm)}

Proses pengolahan air limbah dengan proses biofilm atau biofilter tercelup dilakukan dengan cara mengalirkan air limbah ke dalam reaktor biologis yang di dalamnya diisi dengan media penyangga untuk pengebang-biakan mikroorganisme dengan atau tanpa aerasi. Untuk proses anaerobik dilakukan tanpa pemberian udara atau oksigen. Posisi media biofilter tercelup di bawah permukaan air. Media biofilter yang digunakan secara umum dapat berupa bahan material organik atau bahan material anorganik.

Untuk media biofilter dari bahan organik misalnya dalam bentuk tali, bentuk jaring, bentuk butiran tak teratur (random packing), bentuk papan (plate), bentuk sarang tawon dan lain-lain. Sedangkan untuk media dari bahan anorganik misalnya batu pecah (split), kerikil, batu marmer, batu tembikar, batu bara (kokas) dan lainnya.

Di dalam proses pengolahan air limbah dengan sistem biofilter tercelup aerobik, sistem suplai udara dapat dilakukan dengan berbagai cara. Beberapa cara yang sering digunakan antara lain aerasi samping, aerasi tengah (pusat), aerasi merata seluruh permukaan, aerasi eksternal, aerasi dengan "air lift pump", dan aersi dengan sistem mekanik. Masingmasing cara mempunyai keuntungan dan kekurangan. Sistem aerasi juga tergantung dari jenis media maupun efisiensi yang diharapkan. Penyerapan oksigen dapat terjadi disebabkan terutama karena aliran sirkulasi atau aliran putar kecuali pada sistem aerasi merata seluruh permukaan media.

$\mathrm{Di}$ dalam proses biofilter dengan sistem aerasi merata, lapisan mikroorganisme yang melekat pada permukaan media mudah terlepas, sehingga seringkali proses menjadi tidak stabil. Tetapi di dalam sistem aerasi melalui aliran putar, kemampuan penyerapan oksigen hampir sama dengan sistem aerasi dengan menggunakan difuser, oleh karena itu untuk penambahan jumlah beban yang besar sulit dilakukan. Berdasarkan hal tersebut diatas belakangan ini penggunaan sistem aerasi merata banyak dilakukan karena mempunyai kemampuan penyerapan oksigen yang besar.

Jika kemampuan penyerapan oksigen besar maka dapat digunakan untuk mengolah air limbah dengan beban organik (organic loading) yang besar pula. Oleh karena itu diperlukan juga media biofilter yang dapat melekatkan mikroorganisme dalam jumlah yang besar. Biasanya untuk media biofilter dari bahan anaorganik, semakin kecil diameternya luas permukaannya semakin besar, sehinggan jumlah mikroorganisme yang dapat dibiakkan juga menjadi besar pula. Jika sistem aliran dilakukan dari atas ke bawah (down flow) maka sedikit banyak terjadi efek filtrasi sehingga terjadi proses penumpukan lumpur organik pada bagian atas media yang dapat mengakibatkan penyumbatan. Oleh karena itu perlu proses pencucian secukupnya. Jika terjadi penyumbatan maka dapat terjadi aliran singkat (short pass) dan juga terjadi penurunan jumlah aliran sehingga kapasitas pengolahan dapat menurun secara drastis.

Untuk media biofilter dari bahan organik banyak yang dibuat dengan cara dicetak dari bahan tahan karat dan ringan misalnya PVC dan lainnya, dengan luas permukaan spesifik yang besar dan volule rongga (porositas) yang besar, sehingga dapat melekatkan mikroorganisme dalam jumlah yang besar dengan resiko kebuntuan yang sangat kecil. Dengan demikian memungkinkan untuk pengolahan air limbah dengan beban konsentrasi yang tinggi serta efisiensi pengolahan yang cukup besar. Beberapa contoh perbandingan luas permukaan spesifik dari berbagai media biofilter dapat dilihat pada Tabel 1.

Tabel 1 : Perbandingan luas permukaan spesifik media biofilter.

\begin{tabular}{|c|l|c|}
\hline No. & \multicolumn{1}{|c|}{ Jenis Media } & $\begin{array}{c}\text { Luas permukaan } \\
\text { spesifik }\left(\mathrm{m}^{2} / \mathrm{m}^{3}\right)\end{array}$ \\
\hline 1 & $\begin{array}{l}\text { Trickling Filter } \\
\text { dengan batu pecah }\end{array}$ & $100-200$ \\
2 & $\begin{array}{l}\text { Modul Sarang } \\
\text { Tawon (honeycomb } \\
\text { modul) }\end{array}$ & $150-240$ \\
3 & Bioball & 240 \\
4 & Tipe Jaring & 50 \\
& RBC & $80-150$ \\
\hline
\end{tabular}


Pengolahan air limbah dengan proses biofim tercelup mempunyai beberapa keunggulan antara lain :

\section{1) Pengoperasiannya mudah}

Di dalam proses pengolahan air limbah dengan sistem biofilm, tanpa dilakukan sirkulasi lumpur, tidak terjadi masalah "bulking" seperti pada proses lumpur aktif (Activated sludge process). Oleh karena itu pengelolaanya sangat mudah.

\section{2) Lumpur yang dihasilkan sedikit}

Dibandingkan dengan proses lumpur aktif, lumpur yang dihasilkan pada proses biofilm relatif lebih kecil. Di dalam proses lumpur aktif antara $30-60 \%$ dari BOD yang dihilangkan (removal BOD) akan diubah menjadi lumpur aktif (biomasa) sedangkan pada proses biofilm hanya sekitar $10-30 \%$. Hal ini disebabkan karena pada proses biofilm rantai makanan lebih panjang dan melibatkan aktifitas mikroorganisme dengan orde yang lebih tinggi dibandingkan pada proses lumpur aktif.

3) Dapat digunakan untuk pengolahan air limbah dengan konsentrasi rendah maupun konsentrasi tinggi.

Oleh karena di dalam proses pengolahan air limbah dengan sistem biofilm mikroorganisme atau mikroba melekat pada permukaan medium penyangga maka pengontrolan terhadap mikroorganisme atau mikroba lebih mudah. Proses biofilm tersebut cocok digunakan untuk mengolah air limbah dengan konsentrasi rendah maupun konsentrasi tinggi.

4) Tahan terhadap fluktuasi jumlah air limbah maupun fluktuasi konsentrasi.

Di dalam proses biofilter, mikro-organisme melekat pada permukaan unggun media, akibatnya konsentrasi biomasa mikro-organisme per satuan volume relatif besar, sehingga relatif tahan terhadap fluktuasi beban organik maupun fluktuasi beban hidrolik.

\section{5) Pengaruh penurunan suhu terhadap} efisiensi pengolahan kecil.

Jika suhu air limbah turun maka aktifitas mikroorganisme juga berkurang, tetapi oleh karena di dalam proses biofilm substrat maupun enzim dapat terdifusi sampai ke bagian dalam lapisan biofilm dan juga lapisan biofilm bertambah tebal maka pengaruh penurunan suhu (suhu rendah) tidak begitu besar.

\subsubsection{Pengolahan Air Limbah Dengan Proses Lumpur Aktif Yang Diisi Dengan Media Penyangga.}

Pengolahan air limbah dengan cara ini adalah sama dengan proses lumpur aktif yang mana di dalam bak aerasi diisi dengan media bioball. Air limbah dimasukkan ke dalam bak aerasi (bioreaktor) sambil diaerasi atau dihembus dengan udara. Media bioball yang dimasukan mempunyai berat jenis lebih kecil dari air sehingga cenderung mengambang ke permukaan air. Media bioball mempunyai luas spesifik yang sangat besar sehingga mikroorganisme akan menempel dan berkembang biak dalam jumlah yang sangat banyak. Pada lapisan bagian bawah bak aerasi (reaktor biologis) mikroorganisme akan tersuspensi di dalam air. Air limpasan dari bak aerasi selanjutnya dialirkan ke dalam bak pengendapan akhir untuk memisahkan lumpur yang mengandung mikroorganisme yang masih aktif untuk disirkulasikan kembali ke dalam bak aerasi untuk proses pengolahan air limbah. Sedangkan cairan supernatan yaitu efluen dari bak pengendapan akhir merupakan air hasil olahan.

\section{TUJUAN PENELITIAN}

Tujuan penelitian ini adalah untuk mengetahui pengaruh variasi waktu tinggal dan rasio resirkulasi terhadap efisiensi pengolahan air limbah domestik dengan proses lumpur aktif yang diisi dengan media penyangga bioball secara aerob. Beberapa parameter yang diamati antara lain adalah BOD, COD, ammonia, dan TSS.

\section{MATERIAL DAN METODA PENELITIAN}

\subsection{Material}

\subsubsection{Air Limbah}

Air limbah yang digunakan untuk penelitian adalah air limbah domestik yang berasal dari salah satu inlet waduk Setiabudi Jakarta Selatan.

\subsubsection{Media Penyangga (Supporting Media)}

Media penyangga yang digunakan adalah media dari bahan thermo tipe bioball dengan spesifikasi seperti pada Tabel 2.

\subsection{Analisa Parameter}

Beberapa parameter yang diamati adalah $\mathrm{pH}$, temperatur, konsentrasi COD, BOD, TSS, ammonia yang masuk reaktor biofilter aerob dan 
konsentrasi COD, BOD, TSS, ammonia yang keluar dari bak pengendapan akhir.

Tabel 2 : Spesifikasi media bioball yang digunakan untuk percobaan.

\begin{tabular}{|lll|}
\hline Tipe & $:$ & $\begin{array}{l}\text { Bioball } \\
\text { (random packing) }\end{array}$ \\
Material & $:$ & thermoplastik \\
Diameter & $:$ & $3,5 \mathrm{~cm}$ \\
Luas Spesifik & $:$ & $\pm 210 \mathrm{~m}^{2} / \mathrm{m}^{3}$ \\
Berat spesifik media & $:$ & $164,34 \mathrm{~kg} / \mathrm{m}^{3}$ \\
Berat jenis & $:$ & $0,973 \mathrm{~kg} / \mathrm{m}^{3}$ \\
Porositas Ronga & $:$ & 0,85 \\
Warna & $:$ & hitam \\
& &
\end{tabular}

\section{Pengukuran $\mathrm{pH}$ :}

Pengukuran $\mathrm{pH}$ dilakukan dengan menggunakan Orion pH meter model SA 520.

\section{Pengukuran Temperatur dan Oksigen Terlarut :}

Pengukuran temperatur dan oksigen terlarut (DO) dilakukan dengan menggunakan DO meter (DO-11P).

\section{Pengukuran BOD dan COD :}

Analisa untuk pengukuran parameter COD yang digunakan adalah metode bikromat $\left(\mathrm{K}_{2} \mathrm{Cr}_{2} \mathrm{O}_{7}\right)$ secara open refluks. (Standart Method No. $5220 \mathrm{C}$ ), sedangkan untuk pengukuran BOD dilakukan dengan metoda Standard Method No. 5220 B ).

\section{Padatan tersuspensi (TSS) :}

Untuk menganalisa parameter ini metode yang digunakan adalah metode gravimetri dengan kertas saring. (Standart Method No. 2540 D)

\section{Ammonium $\left(\mathrm{NH}_{4}{ }^{+}\right)$}

Pemeriksaan ammonium dilakukan dengan metode kalorimetri, yaitu dengan menambahkan pereaksi nessler dan warna yang terbentuk dibandingkan dengan larutan standar dengan alat spektrofotometer dengan panjang gelombang $(\lambda) 420 \mathrm{~nm}$.

\subsection{Metoda Penelitian}

\subsubsection{Model Reaktor}

Desain reaktor yang digunakan untuk penelitian ini terdiri dari bak aerasi (bioreaktor aerob) dan bak pengendap akhir. Bioreaktor aerob atau bak aerasi yang digunakan untuk mengolah air limbah domestik adalah bioreaktor berbentuk silinder kerucut yang terbuat dari bahan fiber glass (FRP) dengan total volume 228 liter. Volume kerja yang digunakan adalah 208 liter. Dimensi bioreaktor aerob dapat dilihat pada Gambar 1. Di dalam bioreaktor diisi dengan media biobal dengan volume sekitar $40 \%$ dari total volume bioreaktor.

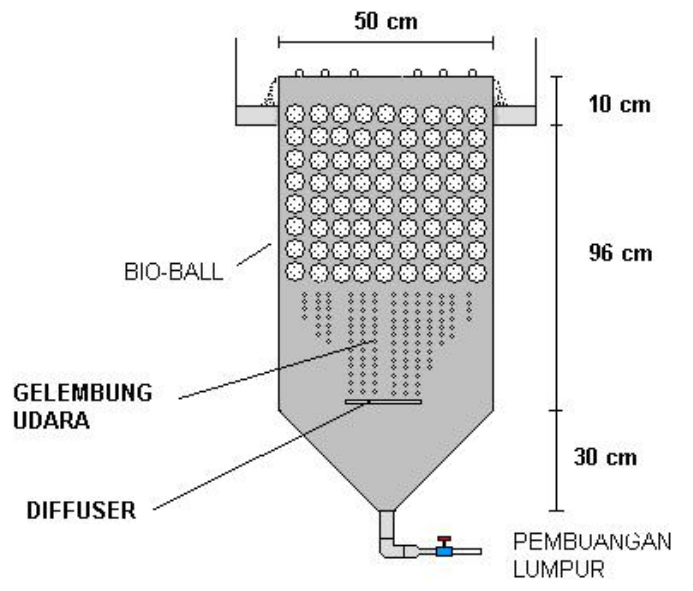

Gambar 1 : Reaktor Biofilter Aerob

Bak pengendap akhir yang digunakan ntuk penelitian berbentuk silinder yang terbuat dari bahan plastik dengan total volume 50 liter, dan volume kerja yang digunakan adalah 40 liter. Waktu tinggal di bak pengendapan sesuai dengan debit limbah yang masuk. Waktu tinggal efektif untuk bak pengendap akhir adalah 1,15 jam. Nilai ini didapat dari waktu tinggal pada bioreaktor aerob, yaitu 6 jam. Skema bak pengendap akhir yang digunakan dalam penelitian ini dapat dilihat pada Gambar 2.

Pengadukan isi bioreaktor dilakukan dengan aerasi merata dengan menggunakan blower (Atman HP-8000) berkapasitas 70 liter/menit yang beroperasi 24 jam. Agar lapisan mikroorganisme yang melekat pada permukaan 
media tidak mudah terlepas, maka dilakukan pengaturan debit udara yang berasal dari blower.

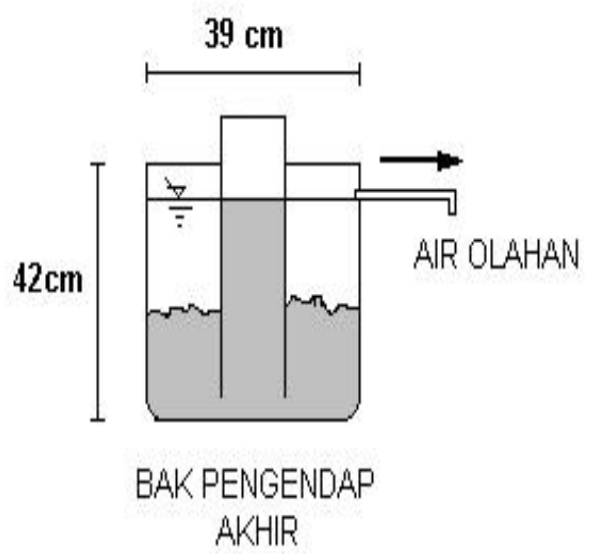

Gambar 2 : Bak Pengendap Akhir.

Lumpur yang mengendap di dalam bak pengendap akhir sebagian disirkulasi ke bak aerasi (bioreaktor aerob) dengan menggunakan pompa sirkulasi (Lifetech AP 2800) yang beroperasi selama 24 jam. Sirkulasi ini dilakukan untuk mengembalikan lumpur yang masih mengandung biomassa yang akan menguraikan zat organik yang masuk ke dalam reaktor.

\subsection{Metoda Percobaan}

\subsubsection{Seeding atau Aklimatisasi}

Pengembangbiakan mikroorganisme (seeding) dilakukan untuk menumbuhkan mikroorganisme. Seeding dilakukan secara alami dengan cara mengalirkan air limbah domestik secara kontinyu ke dalam reaktor biofilter. Dalam proses ini telah terbentuk lapisan biofilm yang menyelimuti media bioball. Sedangkan aklimatisasi merupakan pengadaptasian mikroorganisme terhadap air buangan yang akan diolah. Proses aklimatisasi ini berjalan selama 2 minggu dengan waktu tinggal 4 hari dengan debit 52 liter/hari. Akhir dari aklimatisasi adalah ketika efisiensi penurunan konsentrasi COD relatif stabil.

\subsubsection{Proses pengolahan}

Air limbah dipompa dan dialirkan ke dalam bak aerasi (bioreaktor aerob) yang telah diisi dengan dengan media bioball. Debit air yang dimasukkan ke dalam bioreaktor diatur disesuaikan dengan variasi waktu tinggal. Di dalam bioreaktor aerob, air limbah dialirkan ke unggun media bioball dengan arah aliran dari bawah ke atas sambil dihembus dengan udara. Selanjutnya air limpasan dari bioreaktor aerob mengalir ke bak pengendap akhir melalui weir. Lumpur yang mengendap di dalam bak pengendap akhir tersebut disirkulasi ke bioreaktor aerob. Sedangkan air limpasan dari bak pengendap akhir dibuang ke saluran umum.

Setelah proses seeding berjalan selama 2 minggu, pada permukaan media bioball akan tumbuh lapisan mikroorganisme yang akan menguraikan senyawa polutan yang ada di dalam air limbah. Selanjutnya Debit air limbah domestik yang akan diolah diatur agar sesuai dengan waktu tinggal di dalam bioreaktor areob yakni 48 jam, 24 jam, 12 jam dan 6 jam, dengan ratio sirkulasi lumpur sebesar $0,25 \mathrm{Q}$, Tiap-tiap kondisi operasi dengan waktu tinggal tertentu dilakukan analisa kuaitas air limbah sebelum dan sesudah pengolahan.

Analisa kualitas air limbah dilakukan secara periodik dengan cara mengambil contoh air limbah yang masuk ke reaktor biofilter aerob dan air olahan yang keluar dari bak pengendap akhir. Parameter yang diperiksa adalah BOD, COD, TSS, dan ammonia.

Diagram proses pengolahan air limbah domestik yang digunakan pada saat penelitian dapt dilihat pada Gambar 3., sedangkan foto peralatan yang digunakan selama penelitian dapat dilihat pada Gambar 4.

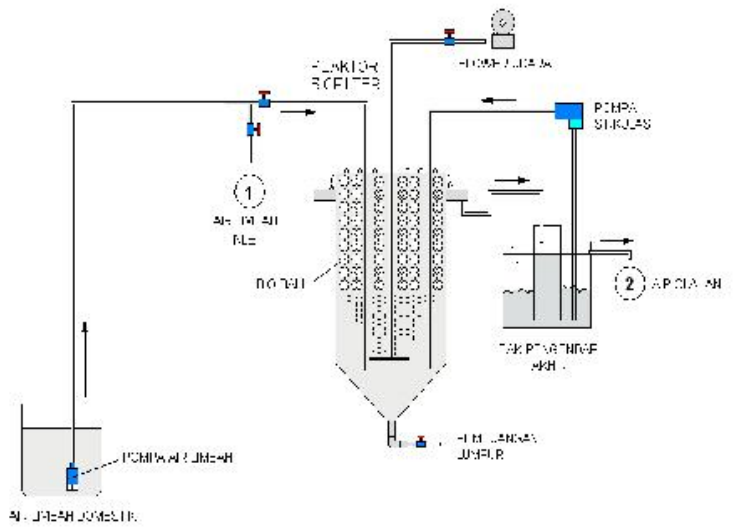

Gambar 1: Diagram proses pengolahan air limbah domestik dengan proses lumpur aktif yang diisi dengan media bioball.

\section{HASIL DAN PEMBAHASAN}

\subsection{Analisa Karakteristik Air Limbah Domestik}

Dari analisa karakteristik air limbah domestik, parameter Total Suspended Solid (TSS), $\mathrm{KmnO}_{4}, \mathrm{BOD}, \mathrm{COD}$, ammonia, minyak dan lemak melebihi baku mutu air limbah domestik berdasarkan PerGub DKI Jakarta No. 122 Tahun 2005. Sedangkan parameter yang sudah memenuhi baku mutu air limbah domestik 
hanya $\mathrm{pH}$ dan detergent. Hal ini dapat dilihat pada Tabel 3.

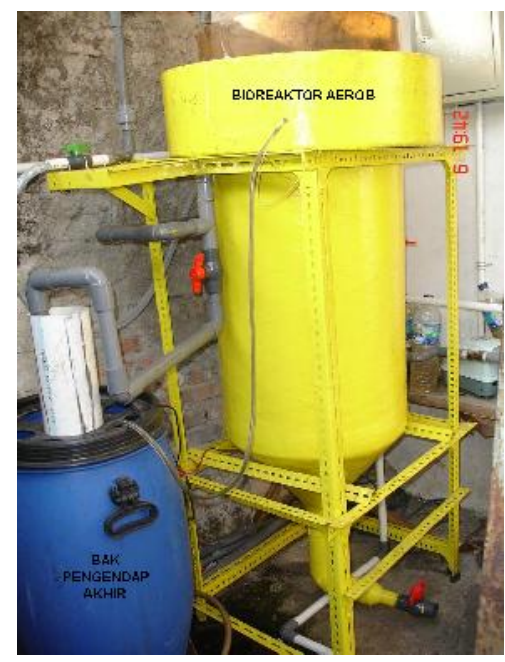

Gambar 4 : Foto bioreaktor yang digunakan selama penelitian.

Tabel 3: Analisa Karakteristik Air Limbah Domestik

\begin{tabular}{|c|c|c|c|}
\hline Parameter & Satuan & $\begin{array}{l}\text { Limbah } \\
\text { Domestik }\end{array}$ & $\begin{array}{l}\text { Baku Mutu } \\
\text { (PerGub DKI } \\
\text { No. } 122 \text { Tahun } \\
\text { 2005) }\end{array}$ \\
\hline TSS & $\mathrm{mg} / \mathrm{l}$ & 130 & 50 \\
\hline $\mathrm{pH}$ & & 7,79 & $6-9$ \\
\hline Organik & $\mathrm{mg} / \mathrm{l}$ & 184,07 & 85 \\
\hline BOD & $\mathrm{mg} / \mathrm{l}$ & 140,45 & 50 \\
\hline COD & $\mathrm{mg} / \mathrm{l}$ & 284,604 & 80 \\
\hline Ammonia & $\mathrm{mg} / \mathrm{l}$ & 15,225 & 10 \\
\hline detergent & $\mathrm{mg} / \mathrm{l}$ & 0,935 & 2 \\
\hline Minyak/Lemak & $\mathrm{mg} / \mathrm{l}$ & 12,125 & 10 \\
\hline
\end{tabular}

Sumber : Hasil Penelitian.

\subsection{Analisa Hasil Seeding (Aklimatisasi)}

Berdasarkan hasil pengamatan setelah lima hari operasi, proses pengolahan belum berjalan dengan baik. Ini dibuktikan dengan efisiensi penyisihan COD kurang dari $50 \%$. Hal ini disebabkan oleh mikroorganisme yang ada di dalam reaktor biofilter aerob belum tumbuh secara optimal. Setelah proses berjalan 2 minggu, mikroorganisme sudah mulai tumbuh dan berkembangbiak di dalam bioreaktor aerob. Di dalam bioreaktor sudah mulai terlihat lapisan mikroorganisme yang menempel pada permukaan media bioball. Dengan berkembangbiaknya mikroorganisme pada permukaan bioball, maka proses penguraian senyawa polutan yang ada dalam air limbah menjadi lebih efektif. Pertumbuhan mikroorganisme diamati dengan mengukur penyisihan COD di dalam reaktor biofilter aerob setelah proses berjalan 2 minggu. Pengukuran dilakukan setiap hari sampai efisiensi penyisihan COD realtif stabil. Grafik konsentrasi COD sebelum dan sesudah pengolahan serta efisiensi penyisihan COD selama proses seeding dapat dilihat pada Gambar 5. Dari data tersebut dapat dilihat bahwa setelah proses seeding berjalan selama 10 (sepuluh) hari efisiensi penyisihan COD mencapai sekitar $90 \%$. Dari pengamatan secara fisik dapat dilihat bahwa setelah dua minggu operasi pada permukaan media bioball telah tumbuh lapisan mikroorganisme yang melekat di permukaan media (Gambar 6).

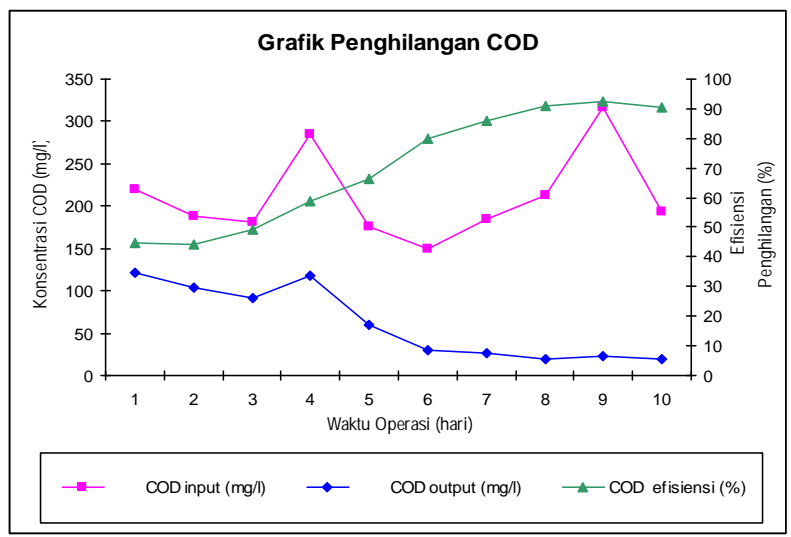

Gambar 5 : Grafik konsentrasi COD sebelum dan sesudah pengolahan serta efisiensi penyisihan COD selama proses seeding.
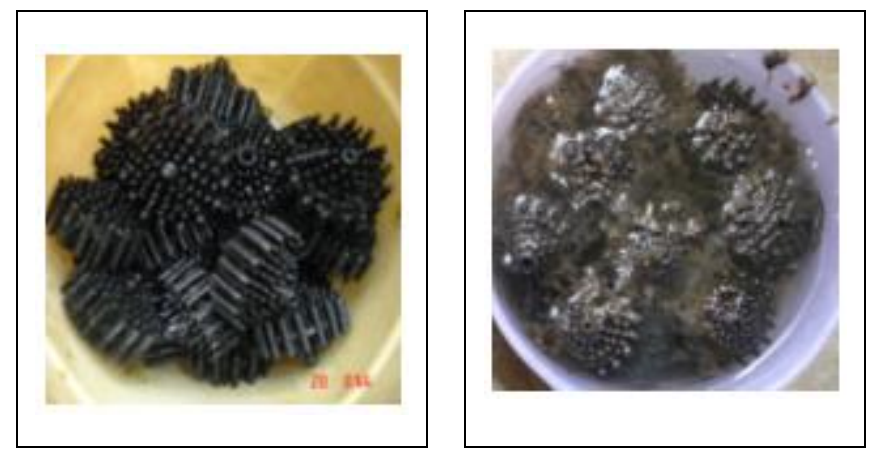

Gambar 6 : Media bioball yang masih baru dan media bioball setelah digunakan selama 2 minggu.

\subsection{Pengaruh Waktu Tinggal (WTH) Terhadap Efisiensi Pengolahan}

\subsubsection{Pengaruh Waktu Tinggal Terhadap Penyisihan COD}

Setelah proses aklimatisasi berjalan dengan baik yaitu ditunjukkan dengan semakin meningkatnya efisiensi penyisihan COD, maka pengoperasian dilanjutkan dengan mengubah 
waktu tinggal di dalam bioreaktor areob yakni 48 jam, 24 jam, 12 jam dan 6 jam, dengan ratio sirkulasi lumpur sebesar $R=0,25 Q$. Dalam pengoperasian ini, debit air limbah disesuaikan dengan waktu tinggal.

Dengan waktu tinggal 48 jam (2 hari) konsentrasi rata-rata COD influen $187,10 \mathrm{mg} / \mathrm{l}$ sedangkan konsentrasi rata-rata COD efluen 23,71 mg/l dengan efisiensi penyisihan COD mencapai 87,23 \%. Untuk waktu tinggal 24 jam (1 hari) konsentrasi rata-rata COD influen 203,69 $\mathrm{mg} / \mathrm{l}$, sedangkan konsentrasi rata-rata COD efluen $28,63 \mathrm{mg} / \mathrm{l}$, dengan efisiensi penyisihan COD rata-rata menjadi $85,96 \%$. Untuk waktu tinggal 12 jam konsentrasi rata-rata COD influen 184,25 mg/l, dan konsentrasi rata-rata COD efluen turun menjadi $30,15 \mathrm{mg} / \mathrm{l}$ dengan efisiensi penyisihan COD 83,64\%. Untuk waktu tinggal 6 jam konsentrasi rata-rata COD influen 204,10 $\mathrm{mg} / \mathrm{l}$, konsentrasi rata-rata COD efluen turun menjadi $42,89 \mathrm{mg} / \mathrm{l}$ dengan efisiensi penyisihan COD mencapai $78,42 \%$.

Pada saat penggantian waktu tinggal menjadi lebih pendek terjadi penurunan efisiensi terlebih dahulu dan setelah $2-3$ hari baru mencapai kestabilan. Penurunan efisiensi pada saat penggantian waktu tinggal terjadi karena adanya perubahan debit aliran dari pengoperasian sebelumnya sehingga beban hidroliknya menjadi lebih besar. Dari hasil penelitian menunjukkan bahwa semakin pendek waktu tinggal pada reaktor maka efisiensi penyisihan COD semakin menurun. Hasil selengkapnya dapat dilihat pada Gambar 7.

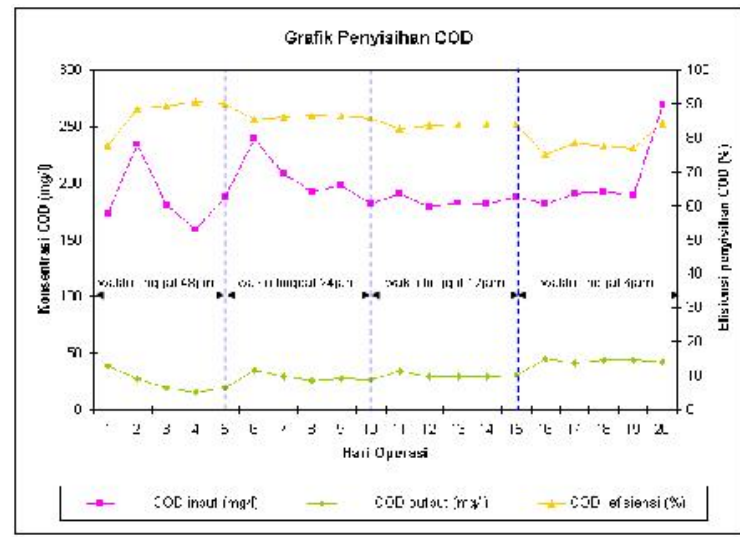

Gambar 7 : Grafik penyisihan COD untuk kondisi berbagai variasi Waktu Tinggal (WTH).

\subsubsection{Pengaruh Waktu Tinggal Terhadap Penyisihan BOD}

Untuk penyisihan BOD mempunyai kecenderungan yang sama dengan penyisihan COD. Dengan waktu tinggal 48 jam (2 hari) konsentrasi rata-rata BOD influen $93,95 \mathrm{mg} / \mathrm{l}$, sedangkan konsentrasi rata-rata $\mathrm{BOD}$ efluen 10,97mg/l, efisiensi penyisihan BOD mencapai $88,03 \%$. Dengan waktu tinggal 24 jam (1 hari) konsentrasi BOD influen rata-rata sebesar 96 $\mathrm{mg} / \mathrm{l}$, sedangkan konsentrasi rata-rata BOD efluen turun menjadi 13,52 $\mathrm{mg} / \mathrm{l}$, dengan demikian efisiensi rata-rata penyisihan BOD $85,74 \%$. Untuk waktu tinggal 12 jam konsentrasi rata-rata $\mathrm{BOD}$ influen 92,21 $\mathrm{mg} / \mathrm{l}$, sedangkan konsentrasi rata-rata BOD efluen 15,16 mg/l, efisiensi rata-rata penyisihan $\mathrm{BOD} 83,56 \%$. Untuk Waktu tinggal 6 jam konsentrasi rata-rata BOD influen 96,02 mg/l, sedangkan konsentrasi rata-rata $\mathrm{BOD}$ efluen i 19,35 $\mathrm{mg} / \mathrm{l}$,efisiensi ratarata penyisihan BOD $79,41 \%$.

Penurunan efisiensi pada saat penggantian waktu tinggal terjadi karena adanya perubahan debit aliran dari pengoperasian sebelumnya sehingga beban hidroliknya menjadi lebih besar. Dari hasil penelitian menunjukkan bahwa semakin pendek waktu tinggal pada bioreaktor maka efisiensi penyisihan BOD semakin menurun. Grafik penyisihan BOD untuk kondisi berbagai variasi Waktu Tinggal (WTH) secara lengkap dapat dilihat pada Gambar 8 .

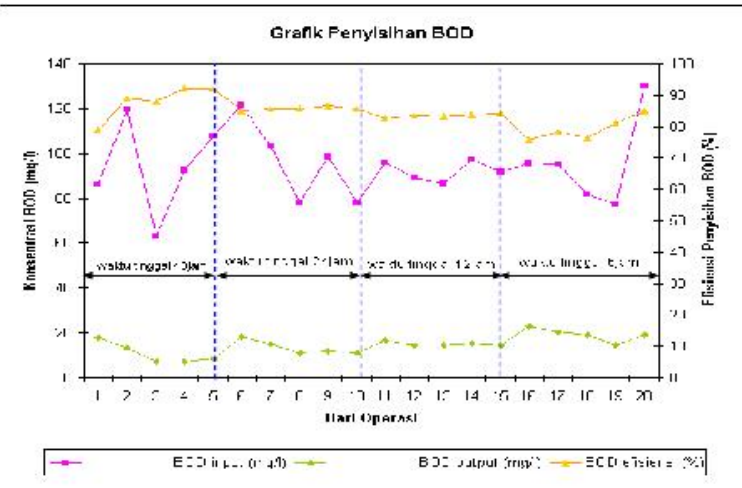

Gambar 8 : Grafik penyisihan BOD untuk kondisi berbagai variasi Waktu Tinggal (WTH).

\subsubsection{Pengaruh Waktu Tinggal Terhadap Penyisihan Ammonia}

Dari hasil penelitian, terlihat bahwa pada kondisi operasi dengan waktu tinggal 48 jam (2 hari) konsentrasi rata-rata ammonia influen 9,67 $\mathrm{mg} / \mathrm{l}$, konsentrasi rata-rata ammonia efluen 2,72mg/l, dengan demikian efisiensi penyisihan ammonia mencapai $72,05 \%$. Dengan waktu tinggal 24 jam (1 hari) konsentrasi rata-rata ammonia influen $13,13 \mathrm{mg} / \mathrm{l}$, konsentrasi ratarata ammonia efluen $3,53 \mathrm{mg} / \mathrm{l}$, efisiensi penyisihan ammonia 71,97\%. Untuk waktu tinggal 12 jam konsentrasi rata-rata ammonia influen $8,2 \mathrm{mg} / \mathrm{l}$, konsentrasi rata-rata ammonia efluen turun 2,61, efisiensi rata-rata penyisihan ammonia 68,27\%. Untuk waktu tinggal 6 jam konsentrasi rata-rata ammonia influen 11,43 $\mathrm{mg} / \mathrm{l}$, konsentrasi rata-rata ammonia efluen 4,36 
$\mathrm{mg} / \mathrm{l}$, efisiensi rata-rata penyisihan ammonia $61,41 \%$. Pada saat penggantian waktu tinggal, terjadi penurunan efisiensi karena adanya perubahan debit aliran dari pengoperasian sebelumnya sehingga beban hidroliknya menjadi lebih besar. Dengan demikian, semakin pendek waktu tinggal pada reaktor maka efisiensi penyisihan ammonia semakin menurun. Hasil selengkapnya dapat dilihat pada Gambar 9.

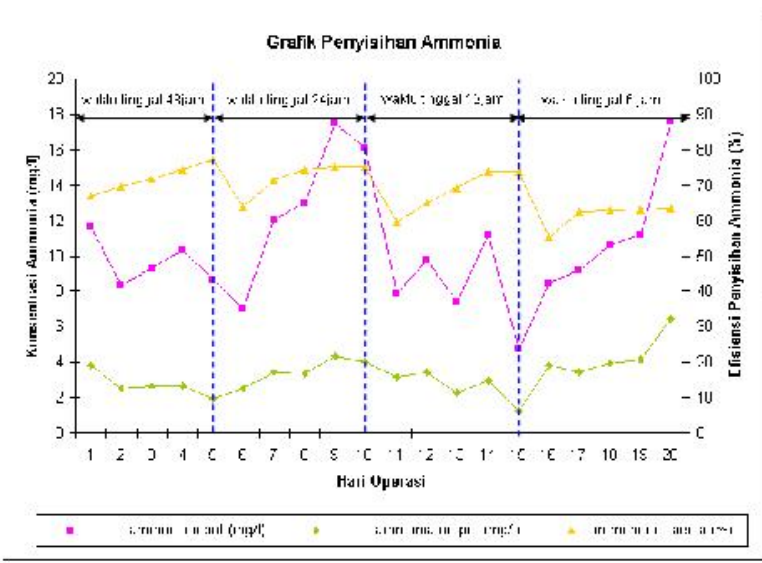

Gambar 9 : Grafik penyisihan Ammonia untuk kondisi berbagai variasi Waktu Tinggal (WTH).

\subsubsection{Pengaruh Waktu Tinggal Terhadap Penyisihan TSS}

Pada saat operasi dengan waktu tinggal 48 jam ( 2 hari) konsentrasi TSS influen rata-rata $77,2 \mathrm{mg} / \mathrm{l}$, konsentrasi rata-rata TSS efluen 6 $\mathrm{mg} / \mathrm{l}$, efisiensi rata-rata penyisihan TSS $90,75 \%$. Dengan waktu tinggal 24 jam (1 hari) konsentrasi rata-rata TSS influen $41,8 \mathrm{mg} /$, I sedangkan konsentrasi TSS efluen $4,8 \mathrm{mg} / \mathrm{l}$, efisiensi ratarata penyisihan TSS 88,39\%. Untuk waktu tinggal 12 jam konsentrasi TSS influen rata-rata 25,2 mg/l, konsentrasi rat-rata TSS efluen 4,2 $\mathrm{mg} / \mathrm{l}$, efisiensi rata-rata penyisihan TSS $84,6 \%$. Untuk waktu tinggal 6 jam konsentrasi rata-rata TSS influen $47,6 \mathrm{mg} / \mathrm{l}$, konsentrasi rata-rata TSS efluen $8,4 \mathrm{mg} / \mathrm{l}$, efisiensi rata-rata penyisihan TSS $82,06 \%$. Pengaruh waktu tinggal hidrolis (WTH) terhadap penyisihan TSS secara lengkap dapat dilihat pada Gambar 10.

Berdasarkan Gambar 10, dapat dilihat bahwa pada saat penggantian waktu tinggal menjadi lebih pendek terjadi penurunan efisiensi terlebih dahulu setelah itu baru mencapai kestabilan. Penurunan efisiensi pada saat penggantian waktu tinggal terjadi karena debit aliran menjadi lebih kecil dari pengoperasian sebelumnya sehingga beban hidroliknya menjadi lebih besar. Dari hasil penelitian menunjukkan bahwa semakin pendek waktu tinggal pada reaktor maka efisiensi penyisihan TSS semakin menurun.

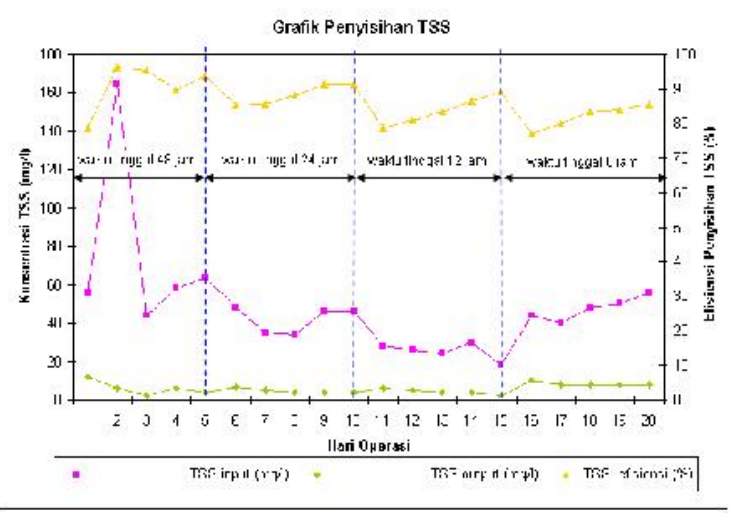

Gambar 10 : Grafik Penyisihan TSS pada Berbagai Variasi Waktu Tinggal (WTH).

\subsection{Pengaruh Rasio Sirkulasi Lumpur Terhadap Efisiensi Pengolahan}

\subsubsection{Pengaruh Rasio Sirkulasi Lumpur Terhadap Efisiensi Penyisihan COD}

Untuk mengetahui pengarug ratio sirkulasi lumpur terhadap efisiensi penyisihan, penelitian dilakukan pada kondisi operasi dengan waktu tinggal 6 jam dengan debit 34,67 liter/jam. Variabel ratio sirlukasi lumpur (R) dilakukan pada konsisi $R=0,25 \mathrm{Q} ; \mathrm{R}=0,5 \mathrm{Q}$; dan $\mathrm{R}=1 \mathrm{Q}$.

Dari hasil penelitian dapat dilihat bahwa efisiensi penyisihan COD rata-rata untuk $\mathrm{R}=0,25 \mathrm{Q}$ adalah $78,42 \%$, untuk $\mathrm{R}=0,5 \mathrm{Q}$ adalah $82,42 \%$ dan $\mathrm{R}=1 \mathrm{Q}$ adalah $67,48 \%$. Perbedaan efisiensi disebabkan karena air hasil olahan disirkulasi kembali sehingga beban hidrolik reaktor biofilter menjadi berubah-ubah. Dari nilai efisiensi ini dapat disimpulkan pada rasio resirkulasi $0,5 \mathrm{Q}$ terjadi penyisihan $\mathrm{COD}$ secara optimum. Hal ini terjadi karena biomassa yang disirkulasi kembali ke bioreaktor cukup optimum untuk menguraikan COD yang terkandung dalam air limbah domestik. Hasil selengkapnya dapat dilihat pada Gambar 11.

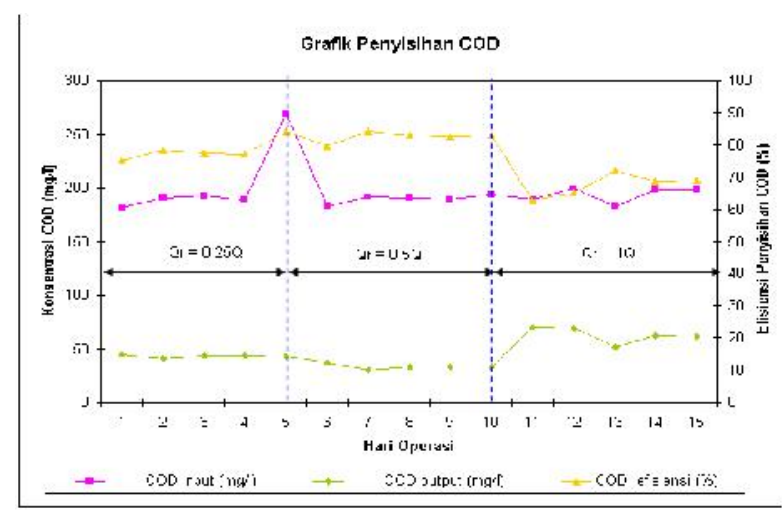

Gambar 11 : Grafik Penyisihan COD pada Berbagai Variasi Rasio Sirkulasi Lumpur. 


\subsubsection{Analisa Efisiensi Penyisihan BOD pada Berbagai Variasi Rasio Resirkulasi}

Untuk penyisihan BOD mempunyai kecenderungan yang sama dengan penyisihan COD. Efisiensi penyisihan $B O D$ rata-rata untuk $\mathrm{R}=0,25 \mathrm{Q}$ adalah $79,41 \%, \quad \mathrm{R}=0,5 \mathrm{Q}$ adalah sebesar $83,11 \%$ dan $\mathrm{R}=1 \mathrm{Q}$ adalah $66,08 \%$. Perbedaan efisiensi disebabkan karena air hasil olahan disirkulasi kembali sehingga beban hidrolik bioreaktor menjadi berubah-ubah. Dari nilai efisiensi ini dapat disimpulkan pada rasio resirkulasi $0,5 \mathrm{Q}$ terjadi penyisihan $\mathrm{BOD}$ secara optimum karena biomassa yang disirkulasi kembali ke bioreaktor cukup optimum. (Gambar 12).

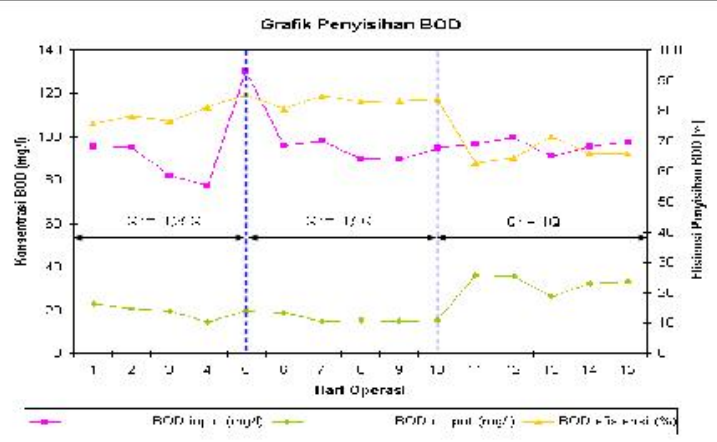

Gambar 12 : Grafik Penyisihan BOD pada Berbagai Variasi Rasio Resirkulasi

\subsubsection{Analisa Efisiensi Penyisihan Ammonia pada Berbagai Variasi Rasio Resirkulasi}

Efisiensi penyisihan ammonia rata-rata untuk $R=0,25 \mathrm{Q}$ adalah $61,41 \%, R=0,5 \mathrm{Q}$ adalah sebesar $78,45 \%$, dan untuk $\mathrm{R}=1 \mathrm{Q}$ adalah $62,29 \%$. Perbedaan efisiensi disebabkan karena air hasil olahan disirkulasi kembali sehingga beban hidrolik bioreaktor menjadi berubah-ubah. Dari nilai efisiensi ini dapat disimpulkan pada rasio resirkulasi $0,5 \mathrm{Q}$ terjadi penyisihan ammonia secara optimum. Hal ini terjadi karena biomassa yang disirkulasi kembali ke bioreaktor cukup optimum. (Gambar 13).

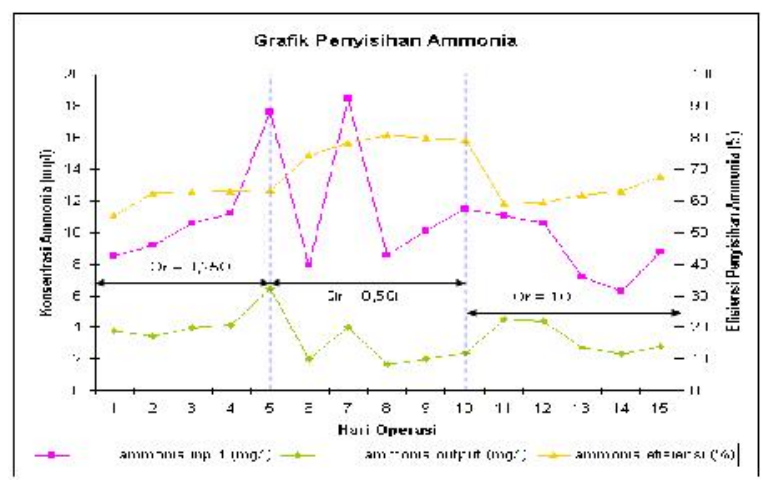

Gambar 13 : Grafik Penyisihan Ammonia pada Berbagai Variasi Rasio Resirkulasi.

\subsubsection{Analisa Efisiensi Penyisihan TSS pada Berbagai Variasi Rasio Resirkulasi}

Efisiensi penyisihan TSS rata-rata untuk $\mathrm{R}=0,25 \mathrm{Q}$ adalah $82,06 \%, \quad \mathrm{R}=0,5 \mathrm{Q}$ adalah $83,38 \%$ dan $\mathrm{R}=1 \mathrm{Q}$ adalah $78,07 \%$. Perbedaan efisiensi disebabkan karena air hasil olahan disirkulasi kembali sehingga beban hidrolik bioreaktor menjadi berubah-ubah. Dari nilai efisiensi ini dapat disimpulkan pada rasio resirkulasi $0,5 \mathrm{Q}$ terjadi penyisihan TSS secara optimum. Hal ini terjadi karena biomassa yang disirkulasi kembali ke bioreaktor cukup optimum. (Gambar 14).

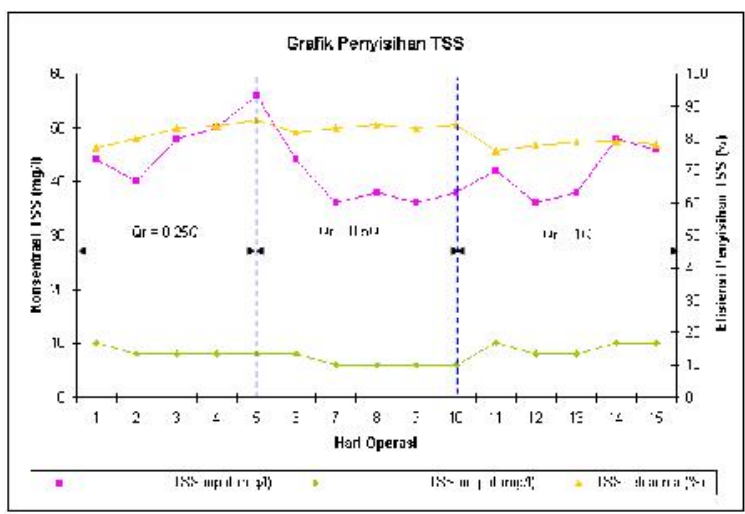

Gambar 14 : Grafik Penyisihan TSS pada Berbagai Variasi Rasio Resirkulasi.

\subsection{Hubungan Antara Beban Organik (Organic Loading) dengan Efisiensi Penyisihan}

Dari hasil penelitian dapat dibuat hubungan antara besarnya beban organik (COD atau BOD) terhadap efisiensi penyisihan bahan organik (COD atau BOD). Beban organik adalah jumlah senyawa organik (COD atau BOD) yang masuk ke dalam bioreaktor per satuan volume reaktor per satuan waktu, yang dinyatakan sebagai berat organik per satuan volume reaktor per hari. Hubungan antara beban COD yang masuk ke dalam bioreaktor dengan efisiensi penyisihan COD dapat dilihat pada Tabel 4 .

Tabel 4 : Hubungan Beban COD yang Masuk Reaktor dan efisiensi Penyisihan.

\begin{tabular}{|c|c|}
\hline $\begin{array}{c}\text { Beban COD } \\
\text { (Kg COD/ } \mathrm{m}^{3} \text {.hari) }\end{array}$ & $\begin{array}{c}\text { Efisiensi } \\
\text { Penyisihan (\%) }\end{array}$ \\
\hline 0,053 & 91,24 \\
0,094 & 89,95 \\
0,204 & 85,96 \\
0,370 & 84,00 \\
0,816 & 78,42 \\
\hline
\end{tabular}

Sumber : Hasil Perhitungan. 
Dari Tabel 4 dapat dilihat bahwa untuk beban COD sebesar 0,094 kg COD/ $\mathrm{m}^{3}$.hari efisiensi penyisihan COD mencapai $89,95 \%$. Sedangkan untuk beban COD sebesar 0,204 kg COD/ $\mathrm{m}^{3}$.hari, efisiensi penyisihan COD turun menjadi 85,96\%. Untuk beban COD sebesar $0,816 \mathrm{~kg} \mathrm{COD} / \mathrm{m}^{3}$.hari, efisiensi penyisihan COD hanya $78,42 \%$. Dari hasil perhitungan Tabel 4 dapat diplotkan dalam bentuk grafik hubungan antara beban COD dengan efisiensi penyisihan yang dapat dilihat pada Gambar 15.

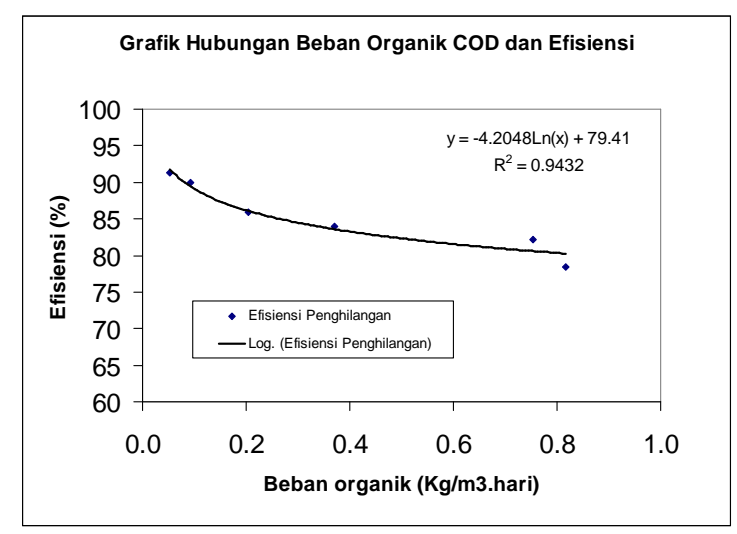

Gambar 15 : Grafik Hubungan Beban Organik COD dengan Efisiensi Penyisihan dalam Bioreaktor Aerob pada Berbagai Variasi Waktu Tinggal (WTH). Sumber : Hasil Penelitian.

Dari Gambar 15 dapat disimpulkan bahwa semakin besar beban organik yang masuk ke dalam bioreaktor maka efisiensi penyisihannya semakin kecil. Pola penurunan efisiensi penyisihan COD mengikuti persamaan logaritma $y=-4,2048 \operatorname{Ln}(x)+79,41$ dengan $x=$ beban organik (kg COD $/ \mathrm{m}^{3}$.hari) dan $\mathrm{y}=$ efisiensi penyisihan COD (\%). Tanda negatif pada persamaan tersebut berarti semakin besar beban organik maka efisiensi penyisihannya semakin menurun. Dari hasil tersebut dapat diketahui bahwa dengan beban COD 0,3 -0,8 kg $\mathrm{COD} / \mathrm{m}^{3}$.hari, efisiensi penyisihan COD berkisar antara $80-85 \%$.

Hubungan antara beban BOD yang masuk ke dalam bioreaktor dengan efisiensi penyisihan BOD dapat dilihat pada Tabel 5.

Tabel 5 :Hubungan Beban BOD yang Masuk Bioreaktor dan efisiensi Penyisihan.

\begin{tabular}{|c|c|}
\hline $\begin{array}{c}\text { Beban BOD }(\mathrm{Kg} \mathrm{BOD} / \\
\mathrm{m}^{3} \text {.hari) }\end{array}$ & $\begin{array}{c}\text { Efisiensi Penyisihan } \\
(\%)\end{array}$ \\
\hline 0,077 & 95,16 \\
0,130 & 88,03 \\
0,266 & 85,74 \\
0,510 & 83,56 \\
1,065 & 79,41 \\
\hline
\end{tabular}

Dari Tabel 5 dapat dilihat bahwa untuk beban BOD sebesar 0,077 kg BOD/ $\mathrm{m}^{3}$.hari, efisiensi penyisihan BOD mencapai $95,16 \%$. Sedangkan untuk beban BOD sebesar 0,266 kg $\mathrm{BOD} / \mathrm{m}^{3}$.hari, efisiensi penyisihan BOD turun menjadi $85,74 \%$. Untuk beban BOD sebesar $1,065 \mathrm{~kg} \mathrm{BOD} / \mathrm{m}^{3}$.hari, efisiensi penyisihan BOD hanya $79,41 \%$. Dari data hasil perhitungan Tabel 5 dapat diplotkan dalam bentuk grafik yang dapat dilihat pada Gambar 16.

Grafik Hubungan Beban Organik BOD dan Efisiensi

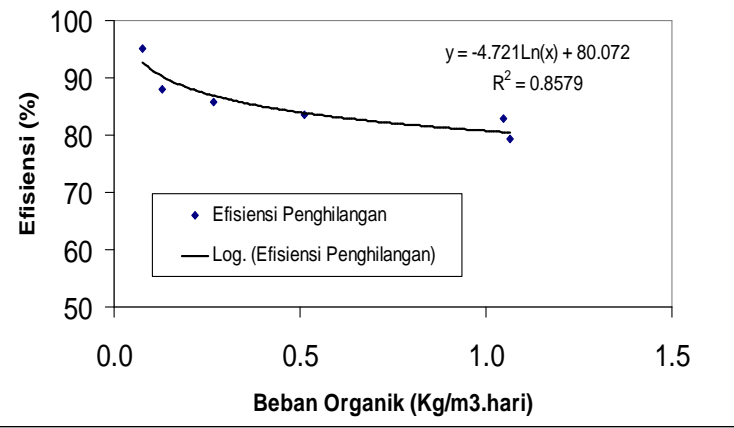

Gambar 16 : Grafik Hubungan Beban Organik BOD dengan Efisiensi Penyisihan dalam Bioreaktor Aerob pada Berbagai Variasi Waktu Tinggal (WTH).Sumber : Hasil Penelitian.

Dari Gambar 16 dapat disimpulkan bahwa semakin besar beban organik yang masuk ke dalam bioreaktor maka efisiensi penyisihannya semakin kecil. Pola penurunan efisiensi penyisihan BOD mengikuti persamaan logaritma $y=-4,721 \operatorname{Ln}(x)+80,072$ dengan $x=$ beban organik ( $\mathrm{kg} \mathrm{BOD} / \mathrm{m}^{3}$.hari) dan $\mathrm{y}=$ efisiensi penyisihan BOD (\%). Tanda negatif pada persamaan tersebut berarti semakin besar beban organik maka efisiensi penyisihannya semakin menurun. Dari gambar tersebut dapat dilihat bahwa dengan beban BOD 0,3 - 1,0 kg $\mathrm{BOD} / \mathrm{m}^{3}$.hari, efisiensi penyisihan BOD berkisar antara $80-85 \%$.

\section{KESIMPULAN}

1. Pengolahan air limbah domestik dengan proses lumpur aktif yang diisi dengan media bioball cukup efektif untuk menurunkan polutan organik, ammonia serta total padatan tersuspensi. Semakin lama waktu tinggal air limbah di dalam bioreaktor, maka efisiensi penyisihan BOD, COD, TSS, dan ammonia juga semakin besar

2. Pada kondisi operasional dengan waktu tinggal di dalam bioreaktor 6 jam dan ratio sirkulasi lumpur $R=0,25 \mathrm{Q}$, konsentrasi $C O D$ di dalam air limbah rata-rata 204,10 mg/l dan 
setelah proses pengolahan dapat diturunkan menjadi $42,89 \mathrm{mg} / \mathrm{l}$, dengan efisiensi penyisihan COD $78,42 \%$. Konsentrasi ratarata ammonia di dalam air limbah $11,43 \mathrm{mg} / \mathrm{l}$ dan setelah proses pengolahan konsentrasi rata-rata ammonia dapat diturunkan menjadi 4,36 $\mathrm{mg} / \mathrm{l}$, dengan efisiensi rata-rata penyisihan ammonia $61,41 \%$. Sedangkan untuk konsentrasi rata-rata TSS sebelum pengolahan $47,6 \mathrm{mg} / \mathrm{l}$, dan setelah proses pengolahan turun menjadi $8,4 \mathrm{mg} / \mathrm{l}$, dengan efisiensi rata-rata penyisihan TSS $82,06 \%$.

3. Rasio re sirkulasi lumpur yang paling efektif adalah 0,5Q. Dengan rasio resirkulasi $0,5 \mathrm{Q}$, efisiensi penghilangan COD mencapai $82,42 \%$, BOD mencapai $83,11 \%$, TSS mencapai $83,38 \%$ dan ammonia mencapai $78,45 \%$.

4. Semakin besar beban organik yang masuk ke dalam bioreaktor maka efisiensi penyisihannya semakin kecil. Dengan beban BOD 0,3-1,0 $\mathrm{kgBOD} / \mathrm{m}^{3}$.hari efisiensi penyisihan BOD berkisar antara $80-85 \%$.

\section{DAFTAR PUSTAKA}

1. ---- " The Study On Urban Drainage And Waste Water Disposal Project In The City Of Jakarta", , JICA, December 1990

2. Benefield, Larry D., Clifford, W. Randall, 1980, Biological Process Desain for Wastewater Treatment, Prentice - Hall, Inc., USA.

3. Droste, Ronald. 1997. Theory and Practice of Water and Wastewater treatment. John Willey and Sons Inc : New York.

4. Gaudy, A.F., Jr. and E.T. Gaudy. 1988. Elements of Bioenvironmental Engineering. Engineering Press, san Jose, CA.
5. Gesuidou Shisetsu Sekkei Shishin To Kaisetsu, Nihon Gesuidou Kyoukai (Japan Sewage Work Assosiation, JSWA), 1979.

6. Hammer, M.J., Water and Wastewater Technology. Wiley, New York. 1986).

7. Keputusan Gubernur DKI Jakarta Nomor 122 Tahun 2005 Tentang Pengelolaan Air Limbah Domestik di Wilayah Prov. DKI Jakarta. KPPL DKI Jakarta, 2005.

8. Kurozawa, dkk. : "Seibutsu kasseitan shori ni okeru gendaku busshitsu, amoniasei chisso, tetsu oyobi mangan no jokyo", Suishitsu odaku kenkyu, 11 (9) 577-589 (1988).

9. Metcalf And Eddy, " Waste Water Engineering", Mc Graw Hill. 1991.

10. Miller, G. W., Rice. R. G. : “European Treatment Practice - The Promise Of Biological Activated Carbon", Civil Eng., 48 (2) 81 (1978).

11. Nakano, S., Tamura, T. : "Seibutsu kasseitan ni yoru mizushori gijutsu", Kogyou yousui No.441 (12) 41 - 51 (1992).

12. Said, N. I dan Hidayati Suly Meilani. 2000. Penghilangan Polutan Organik di Dalam Air Baku Air Minum Dengan Proses Biofilter Tercelup Menggunakan Media Plastik Sarang Tawon. Jurnal Sains dan Teknologi Indonesia. BPPT. Jakarta.

13. Said, Nusa Idaman, 2002, Teknologi Pengolahan Limbah Cair dengan Proses Biologis, BPPT, Jakarta.

14. Sublette, Snider and Sylvister (1982) A Review of the Mechanism of Powdered Activated Carbon Enhancement of Activated Sludge Treatment. Water Research. Vol.16, pp. 1075 to $1082,1982$.

15. Sundstrom, Donald W. dan Herbert E. Klei, 1979, Wastewater Treatment, Prentice Hall, Inc., USA.

16. Weber, W. J. Jr., Hopkins, C. B., Bloom, Jr.:"Physicochemical Treatment Of Waste Water ", Journal Water Pollution Control Federation, 42 (1) 83-99 (1970). 